\title{
Stem cells: potential source for retinal repair and regeneration
}

\author{
Células tronco: fonte potencial para a regeneração retiniana
}

\author{
Leonardo Torquetti ${ }^{1}$ \\ Paula Castanheira ${ }^{2}$ \\ Alfredo Miranda de Góes ${ }^{3}$ \\ Marcio Nehemy ${ }^{4}$
}

\begin{tabular}{l} 
ABSTRACT \\
\hline Stem cells have been studied in several fields of Medicine, and their \\
applications are not too far from the clinical practice. Retinal impairment \\
by neuronal death has been considered incurable due to the limited \\
regenerative capacity of the central nervous system. The capacity of \\
stem cells to regenerate tissues, as well as their plasticity makes them a \\
potential source for retinal repair. The stem cells are a great promise for \\
the therapy of inherited retinal disorders and retinal-neuronaldegenerative \\
diseases, such as retinitis pigmentosa and allied retinal dystrophies, \\
which can result in blindness. Because of the accessibility, expansibility, \\
and multipotentiality mesenchymal stem cells are expected to be useful \\
for clinical applications, especially in regenerative medicine and tissue \\
engineering. Mesenchymal stem cells are clonogenic, nonhematopoietic \\
stem cells present in the bone marrow. Given the appropriate microenvi- \\
ronment, they could differentiate into cardiomyocytes or even into cells \\
of nonmesodermal derivation including hepatocytes and neurons. So far, \\
the results of a few studies are consistent with the belief that cell-based \\
therapies using mesenchymal stem cells may be effective when it comes \\
to retinal damaged tissue repair.
\end{tabular}

Keywords: Stem cells; Regeneration/physiology; Retina; Mesenchymal stem cells; Retinal ganglion cells
Trabalho realizado na Universidade Federal de Minas Gerais - UFMG - Belo Horizonte (MG) - Brasil.

${ }^{1}$ Doutorando em Oftalmologia pela Universidade Federal de Minas Gerais - UFMG - Belo Horizonte (MG) Brasil.

${ }^{2}$ Doutoranda em Bioquímica e Imunologia pela UFMG Belo Horizonte (MG) - Brasil.

${ }^{3}$ Professor Adjunto do Departamento de Bioquímica e Imunologia, Instituto de Ciências Biológicas da UFMG - Belo Horizonte (MG) - Brasil.

${ }^{4}$ Professor Adjunto do Departamento de Oftalmologia e Otorrinolaringologia, Faculdade de Medicina da UFMG Belo Horizonte (MG) - Brasil.

Endereço para correspondência: Hospital São Geraldo - HC - Universidade Federal de Minas Gerais. Av. Alfredo Balena, 110 - Belo Horizonte (MG) CEP 30130-100 E-mail: leonardotorqueti@yahoo.com.br

Recebido para publicação em 30.01.2006 Última versão recebida em 17.07.2006

Aprovação em 02.08.2006

Nota Editorial: Depois de concluída a análise do artigo sob sigilo editorial e com a anuência do Dr. Ayrton Roberto Branco Ramos sobre a divulgação de seu nome como revisor, agradecemos sua participação neste processo.

\section{STEM CELLS: GENERAL OVERVIEW}

The stem cells have been widely studied in the last few years in virtually all fields of Medicine ${ }^{(1-4)}$, especially in Cardiology ${ }^{(5-6)}$. There are two cardinal principles of stem cells: self-renewal and the multipotentiality to make all of the cell types of the particular tissue to which they belong ${ }^{(7)}$.

The human body contains several types of progenitor cells that are capable of dividing many times, while also giving rise to daughter cells with more restricted developmental potentials. Eventually these cells differentiate and have specific phenotypic characteristics that contribute to their highly specialized function. Examples of such stem cells include the totipotent zygote, as well as embryonic stem cells, hematopoietic stem cells and mesechymal stem cells.

Two types of mammalian pluripotent stem cells have been isolated Embryonic Stem Cells (ES) derived from pre-implantation embryos and Embryonic Germ Cells (EG) derived from primordial germ cells of the postimplantation embryo ${ }^{(8)}$. Embryonic stem cells express the transcription factor Oct-4, which maintains them in an undifferentiated state, with continuous proliferation. However, when these cells are removed from their origin, they begin to differentiate into other tissues even without stimulus. 
As a result of the loss of the Oct-4 factor, in vivo, these cells could differentiate properly or inappropriately forming tumors after transplantation. So, when it comes to transplants, this becomes a very serious safety issue and the ability of these cells to form tumors in histocompatible animals reinforces the idea that it might be better to use differentiated cells, rather than embryonic stem cells for transplantation ${ }^{(8)}$.

Embryonic germ cells express SSEA- ${ }^{(9)}$, a cell surface embryonic antigen, whose functions have been associated with cell adhesion, migration and differentiation and is often differentially expressed during development ${ }^{(10)}$. They are derived from the primordial germ cells, which occur in a specific part of the embryo/fetus called the gonadal ridge, and which normally develop into mature gametes (eggs and sperm). Both ES and EG are able to differentiate into derivatives of all three primary germ layers-endoderm, mesoderm, and ectoderm when culture conditions are adjusted ${ }^{(11)}$.

Hematopoietic stem cells are responsible for the constant renewal of the blood. These cells express CD $34^{(12)}$ and are classically isolated from the bone marrow or blood but they can also be found in the umbilical chord, in the fetal hematopoietic system. They are capable of self-renewal and differentiate in blood and immune system cells, however, their expansibility and differentiation capacity in vitro is decreased ${ }^{(13)}$.

Mesenchymal stem cells are non-hematopoietic, stromal cells that exhibit multilineage differentiation capacity, being capable of giving rise to diverse tissues ${ }^{(14)}$. They are found in a variety of tissues during development, mainly in the bone marrow of adults. These cells can be aspirated directly from iliac crest of the donors ${ }^{(15-17)}$. They are also easily isolated, expanded in culture and stimulated to differentiate into osteoblast ${ }^{(18)}$, condrocytes $^{(19)}$, skeletal muscle cells ${ }^{(20)}$, endothelium ${ }^{(21)}$, cardiac muscle cells ${ }^{(5-6)}$, hepatocytes ${ }^{(22)}$, adipocytes ${ }^{(23)}$, and nonmesoderm-type cells like neurons both in vitro and in vivo ${ }^{(24-25)}$.

The ability of stem cells to migrate to damaged tissue sites and stimulate repairs by differentiation into tissue-specific cells has been already demonstrated in vivo ${ }^{(26)}$.

In fact, different signals such as trauma, fracture, inflammation and necrosis, in vivo, can direct MSCs to mobilize and differentiate into cells of connective tissue lineages as well as other tissue lineages ${ }^{(27-28)}$.

The human mesenchymal stem cells (hMSC) are a population of cells in which a phenotype was determined by analysis of surface molecules by flux citometry, as CD29, CD44, SH2, SH3, CD71, CD90, CD106, CD120a and CD124 ${ }^{(29-32)}$. The ability to isolate, expand and direct the hMSC in vitro in distinct lineages allows to study the events associated with impairment and differentiation of these cells.

Finally, the bone marrow is the most common used source of stem cells. On account of its autologous characteristic, relative easy isolation and less ethical controversial nature when compared to embryonic stem cells, embryonic or bone marrow stem cells become the best choice in the treatment of diseases using cell-based therapy.

\section{STEM CELLS: RETINA REPAIR}

Retinal impairment by neuronal death has been considered incurable because the central nervous system has a limited regenerative capacity. The ability to regenerate and repair damage of the retina is at the center of hopes for the therapeutic use of stem cells in the eye.

In retina regeneration, two events can occur. In one of them, differentiated cells neighboring the damage site go through a natural process of dedifferentiation and subsequently redifferentiate into a specific cell lineage for repair, in a process called transdifferentiation. The other strategy for retinal regeneration is the use of stem cells. Depending on the species, transdifferentiation or stem cells can be recruited to populate damaged retina ${ }^{(33-34)}$

Regeneration of the retina in fish, bird, and amphibian has been observed to take place by a transdifferentiation of the retinal pigment epithelium (RPE). As for embryonic chicks, the transdifferentiation occurs via RPE and multipotent retinal progenitor cells in the ciliary marginal zone (CMZ), a circumferential neurogenic zone located at the extreme peripheral retina ${ }^{(35-36)}$. In adult birds, local retinal damage is repaired by the transdifferentiation of Müller glia cells ${ }^{(37-39)}$. In mammals, once retinal histogenesis is complete, there is no continued production of retinal neurons, and there is no evidence for a CMZ-like growth zone so retina regeneration in these species, even in embryos, is not observed unless their retina is properly induced ${ }^{(40)}$.

However, studies in humans have examined the expression of the neural progenitor marker nestin in retina. Nestin is expressed in some cells at the junction of the neural retina and the ciliary body, which suggests that a remnant of the CMZ may remain in humans ${ }^{(41)}$. Furthermore, it has been reported that neural stem cells (NSC), which are the potential source of several cells in the central nervous system, including neurons, astrocytes and oligodendrocytes could be isolated in vitro from mouse, rat and human remnant ciliary marginal zone; these cells can differentiate into neurons, such as photoreceptors, bipolar neurons and even Müller glia cells in vitro ${ }^{(37,42)}$. This approach, because of the complication of the extraction of these cells which involves microsurgical procedures, is not an option for the treatment of ocular diseases, and it is not clinically feasible, considering also the limited availability of pluripotent retinal stem cells ${ }^{(43)}$. In this case stem cells of other origins (harvested from other tissues) may be a hope for the retinal disorder therapy.

Retinal stem cells are not the only cells capable of retina regeneration. In the search for other sources of possible retinal progenitors in mammals, some authors have found that non-neuronal stem cells present in the eye, such as cells from the iris, corneal limbus, choroid and sclera can be induced to differentiate into retinal cells or at least neural cells ${ }^{(44-46)}$. These cells could also potentially provide a source for replacing damaged retina, but further investigation is needed.

There are plenty of possible sources for retina repair. 
However, the multipotentiality of the MSCs as well as the easy isolation and culture properties and their high expansive potential make these cells the most appropriate source to be used as a therapeutic tool for retinal repair.

It was recently reported that cultured MSCs can be induced in vitro and in vivo to differentiate into non-mesenchymal derivatives such as neural cells ${ }^{(47-48)}$. Tomita et al. injected MSCs into injured rat eyes and observed that they were able to differentiate into retinal neural cells in vivo ${ }^{(49)}$. It was also demonstrated that MSCs can be induced to differentiate into photoreceptors in vitro and in vivo ${ }^{(43)}$. But despite the integration of stem cells in damaged retina layers and their differentiation into retinal cells, there was no evidence of functionality ${ }^{(37,50)}$. In contrast to these studies, another research using electroretinography (ERG), states that the ERG response after stem cell implantation was improved, indicating a functional integration of grafted cells ${ }^{(40)}$.

Taken together, these results suggest that a better understanding of the differentiated stem cell physiology is still needed, before considering the clinical application of these cells. However, it is clear that in the future MSCs could be used as an alternative in the treatment of degenerative retinal diseases and could potentially rescue injured retinal tissue.

\section{CLINICAL APPLICATIONS AND FUTURE DIRECTIONS}

A lot of inherited retinal and retinal-neuronal degenerative diseases, such as retinitis pigmentosa and allied retinal dystrophies can result in blindness. To date, no effective therapies have been developed to prevent or reverse the degenerative processes in these disorders. Studies were undertaken to evaluate the prospects of using stem cell transplantation as a mean of treating those disorders.

The first evidence that cell replacement therapy could be possible in the retina emerged with the observations that adult hippocampal stem cells/progenitors, transplanted into the vitreous of neonatal or adult eyes survived and were incorporated into the laminar structure of the host retina ${ }^{(51-52)}$. It was also recently reported that fetal mesenchymal stem cells have been successfully used already in intrauterine cell transplantation in the treatment of osteogenesis imperfecta, showing that the scope of potential medical indications is wide ${ }^{(53)}$.

When it comes to transplants, stem cells can be grafted into the eye in an undifferentiated state or in a more specialized state, similar to neuronal stem cells. After grafting stem cells in the retina, it is expected that these cells will differentiate into retinal cells and incorporate into the existing tissue. The migration and integration of the transplanted cells in host tissue is probably induced by its injury. According to Chako et al. ${ }^{(54)}$, the widespread migration and incorporation of neural stem cells were observed only in retina that was either disea$\operatorname{sed}^{(52)}$ or traumatized ${ }^{(55)}$. These types of injuries could provide a local milieu (interleukins, chemotaxins, inflammatory and growth factors, etc) which may be responsible for the migration and incorporation of exogenous ocular stem cells.

Studies using the $r d$ mouse model with retinal degeneration demonstrated that one marrow-derived stem cells exert great vasculotrophic and neurotrophic effects on the retina when injected intravitreally ${ }^{(56)}$. This rescue effect is most efficient when stem cells were injected prior to complete retinal degeneration. In the clinical setting, this could be feasible in degenerative disorders such as retinitis pigmentosa, in the early to mid-stages, when theoretically the therapy would be more efficient ${ }^{(57)}$.

A major issue facing stem cell research, and retinal transplantation of stem cells in particular, is the question of functional integration of grafted cells.

Despite the existence of ocular immune privilege, immune rejection is a major barrier to successful retinal transplantation. It is important to evaluate if stem cell grafts in different sites of the retina will survive without disrupting the morphology and laminar organization of the host retina and will not induce the formation of rosettes, which could compromise the functional integration of the graft within the host retina, failing to reconstruct its normal anatomy ${ }^{(53,57-58)}$. It becomes important to determine whether immune privilege is a feature of the subretinal space and the vitreous cavity when grafted with stem cells ${ }^{(25,59)}$.

Jiang et al. demonstrated in mice that retinal allografts, implanted in the subretinal space and vitreous cavity, experienced immune privilege and promoted deviation of immune responses at these sites ${ }^{(60)}$.

Väänänen demonstrated, in rats, that the transplantation of retinal progenitor cells survived in the subretinal space for a prolonged period of time and did not induce the formation of rosettes. In addition, this study suggested that the subretinal space offers a conductive environment for the differentiation of these cells as photoreceptors ${ }^{(53)}$.

In addition to the type of cell to be used, another issue to be investigated is the preferential way to insert the stem cells into the human eye. There are two ways of transplantation: subretinal or intravitreal. They are widely described in the literature and both of them have immune privilege features. The subretinal implantation of stem cells requires a vitrectomy, which is a large and risky procedure. Alternatively, the intravitreal injection is a more popular and much less invasive procedure ${ }^{(61)}$. As the current literature shows that, in rats and mice, there are no differences in both procedures, the intravitreal injection would be the best choice for being less invasive.

In conclusion, there are still many questions to be investigated and much work needs to be done before clinical application of a stem cell-based therapeutic approach in retinal repair could be applied. It is still too early to predict the possibility of a vision rescue of a patient with macular degeneration or retinitis pigmentosa. However, experimental studies point towards this direction. Findings in the field of retinal transplantation and stem cell grafting offer a new opportunity for the development of therapeutic strategies in human eye diseases and open new fields in the study of retinal repair using stem cells. 


\section{RESUMO}

Células-tronco têm sido estudadas em várias áreas da Medicina e suas aplicações brevemente deverão estar incorporadas à prática clínica. O dano retiniano pela morte neuronal é considerado incurável devido a pobre capacidade regenerativa do sistema nervoso central. A capacidade das células-tronco em regenerar tecidos, assim como sua plasticidade, faz que estas sejam uma fonte potencial de células para a regeneração retiniana. Células-tronco são muito promissoras para o tratamento das distrofias retinianas, como a retinose pigmentar e outras doenças neurodegenerativas, que podem evoluir para cegueira. As células-tronco mesenquimais são o tipo mais provável de células-tronco a serem utilizadas na prática clínica devido a sua fácil acessibilidade e multipotencialidade de diferenciação em vários tecidos. As células-tronco mesenquimais são células clonogênicas, não-hematopoiéticas, localizadas na medula óssea. Desde que seja proporcionado um microambiente apropriado, estas células podem se diferenciar em cardiomiócitos e até mesmo em células de origem não-mesodérmica, como hepatócitos e neurônios. Até o presente momento, os resultados dos estudos iniciais são animadores em relação ao uso de células-tronco mesenquimais e uso eficaz destas no reparo de tecidos retinianos lesados.

Descritores: Células-tronco; Regeneração/fisiologia; Retina; Células-tronco mesenquimais

\section{REFERENCES}

1. Blatt A, Cotter G, Leitman M, Krakover R, Kaluski E, Milo-Cotter O, et al Intracoronary administration of autologous bone marrow mononuclear cells after induction of short ischemia is safe and may improve hibernation and ischemia in patients with ischemic cardiomyopathy. Am Heart J. 2005; 150(5):986.

2. Singla DK, Hacker TA, Ma L, Douglas PS, Sullivan R, Lyons GE, et al. Transplantation of embryonic stem cells into the infarcted mouse heart: formation of multiple cell types. J Mol Cell Cardiol. 2005;40(1):195-200.

3. Pallini R, Vitiani LR, Bez A, Casalbore P, Facchiano F, Di Giorgi Gerevini $\mathrm{V}$, et al. Homologous transplantation of neural stem cells to the injured spinal cord of mice. Neurosurgery. 2005;57(5):1014-25; discussion 1014-25.

4. Vilas-Boas F, Feitosa GS, Soares MBP, Pinho-Filho JA, Mota A, Almeida AJG, et al. Transplante de células de medula óssea para o miocárdio em paciente com insuficiência cardíaca secundária á doença de Chagas. Arq Bras Cardiol. 2004;82(2):181-7.

5. Balsam LB, Robbins RC. Haematopoietic stem cells and repair of the ischaemic heart. Clin Sci (Lond). 2005;109(6):483-92.

6. Van Laake LW, Van Hoof D, Mummery CL. Cardiomyocytes derived from stem cells. Ann Med. 2005;37(7):499-512.

7. National Institutes of Health (NIH). Department of Health and Human Services. Stem cells: Scientific Progress and Future Research Directions. [text on the Internet]. [cited 2004 May 24]. Washington; 17 june 2001. Available from: http://stemcells.nih.gov/info/scireport/2001report.htm

8. Donovan PJ, Gearhart J. The end of the beginning for pluripotent stem cells. Nature. 2001;414(6859):92-7.

9. Reubinoff BE, Pera MF, Fong CY, Trounson A, Bongso A. Embryonic stem cell lines from human blastocysts: somatic differentiation in vitro. Nat Biotechnol. 2000;18(4):399-404. Erratum in: Nat Biotechnol 2000;18(5):559. Erratum in: Nat Biotechnol 2000;18(5):559. Comment in: Nat Biotechnol. 2000;18(4):381-2.

10. D'Costa S, Petitte JN. Characterization of stage-specific embryonic antigen-1 (SSEA-1) expression during early development of the turkey embryo. Int J Dev Biol. 1999;43(4):349-56.
11. Pera MF, Reubinoff B, Trounson A. Human embryonic stem cells. J Cell Sci. 2000;113(Pt 1):5-10.

12. Morrison SJ, Uchida N, Weissman IL. The biology of hematopoietic stem cells. Annu Rev Cell Dev Biol. 1995;11:35-71.

13. Baum CM, Weissman IL, Tsukamoto AS, Buckle AM, Peault B. Isolation of a candidate human hematopoietic stem-cell population. Proc Natl Acad Sci USA. $1992 ; 89(7): 2804-8$.

14. Pountos I, Giannoudis PV. Biology of mesenchymal stem cells. Injury. 2005;36 Suppl 3:S8-S12.

15. Bertram H, Mayer H, Schliephake H. Effect of donor characteristics, technique of harvesting and in vitro processing on culturing of human marrow stroma cells for tissue engineered growth of bone. Clin Oral Implants Res. 2005t; 16(5):524-31.

16. Ahrens N, Torment A, Paul's M, Rooster man D, Salaam A, Kern V, et al. Mesenchymal stem cell content of human vertebral bone marrow. Transplantation. 2004;78(6):925-9.

17. Chou SH, Kao CL, Pang CH, Chen SJ, Tang YW, Ku HH, et al. A novel in vitro retinal differentiation model by co-culturing adult human bone marrow stem cells with retinal pigmented epithelium cells. Brioche Biophysics Res Common. 2005;326(3):578-85.

18. Kassel M, Roskilde L, Erikson EF. 1,25-dihydroxyvitamin D3 potentiates fluoride-stimulated collagen type I production in cultures of human bone marrow stromal osteoblast-like cells. J Bone Miner Res. 1993;8(12):1453-8.

19. Johnstone B, Hering TM, Caplan AI, Goldberg VM, Yoo JU. In vitro chondrogenesis of bone marrow-derived mesenchymal progenitor cells. Exp Cell Res. 1998;238(1):265-72.

20. Sampaolesi M, Biressi S, Tonlorenzi R, Innocenzi A, Draghici E, Cusella de Angelis MG, et al. Cell therapy of primary myopathies. Arch Ital Biol. 2005; 143(3-4):235-42.

21. Abedin M, Tintut Y, Demer LL. Mesenchymal stem cells and the artery wall. Circ Res. 2004;95(7):671-6.

22. Lee KD, Kuo TK, Whang-Peng J, Chung YF, Lin CT, Chou SH, Chen JR, Chen YP, Lee OK. In vitro hepatic differentiation of human mesenchymal stem cells. Hepatology. 2004;40(6):1275-84.

23. Justesen J, Stenderup K, Eriksen EF, Kassem M. Maintenance of osteoblastic and adipocytic differentiation potential with age and osteoporosis in human marrow stromal cell cultures. Calcif Tissue Int. 2002;71(1):36-44.

24. Jiang Y, Jahagirdar BN, Reinhardt RL, Schwartz RE, Keene CD, OrtizGonzalez XR, et al. Pluripotency of mesenchymal stem cells derived from adult marrow. Nature. 2002;418(6893):41-9.Comment in: Nature. 2002;418 (6893):1. Nature. 2002;418(6893):25-7.

25. Sanchez-Ramos J, Song S, Cardozo-Pelaez F, Hazzi C, Stedeford T, Willing A, et al. Adult bone marrow stromal cells differentiate into neural cells in vitro. Exp Neurol. 2000;164(2):247-56.

26. De Bari C, Dell'Accio F, Vandenabeele F, Vermeesch JR, Raymackers JM, Luyten FP. Skeletal muscle repair by adult human mesenchymal stem cells from synovial membrane J Cell Biol. 2003;160(6):909-18. Comment in: J Cell Biol. 2003;160(6):807-9.

27. Vaccarino FM, Ganat Y, Zhang Y, Zheng W. Stem cells in neurodevelopment and plasticity. Neuropsychopharmacology. 2001;25(6):805-15.

28. Young HE, Duplaa C, Katz R, Thompson T, Hawkins KC, Boev AN, et al. Adult-derived stem cells and their potential for use in tissue repair and molecular medicine. J Cell Mol Med. 2005;9(3):753-69.

29. Pittenger MF, Mackay AM, Beck SC, Jaiswal RK, Douglas R, Mosca JD, et al. Multilineage potential of adult human mesenchymal stem cells. Science. 1999;284(5411):143-7.

30. Lodie TA, Blickarz CE, Devarakonda TJ, He C, Dash AB, Clarke J, et al. Systematic analysis of reportedly distinct populations of multipotent bone marrow-derived stem cells reveals a lack of distinction. Tissue Eng. 2002; $8(5): 739-51$.

31. Javazon EH, Beggs KJ, Flake AW. Mesenchymal stem cells: paradoxes of passaging. Exp Hematol. 2004;32(5):414-25.

32. Haynesworth SE, Baber MA, Caplan AI. Cell surface antigens on human marrow-derived mesenchymal cells are detected by monoclonal antibodies. Bone. 1992;13(1):69-80.

33. Haynes T, Del Rio-Tsonis K. Retina repair, stem cells and beyond. Curr Neurovasc Res. 2004;1(3):231-9.

34. Mitsuda S, Yoshii C, Ikegami Y, Araki M. Tissue interaction between the retinal pigment epithelium and the choroid triggers retinal regeneration of the newt Cynops pyrrhogaster. Dev Biol. 2005;280(1):122-32.

35. Spence JR, Madhavan M, Ewing JD, Jones DK, Lehman BM, Del RioTsonis K. The hedgehog pathway is a modulator of retina regeneration. Development. 2004;131(18):4607-21. 
36. Fischer, AJ. and Reh, TA. Identification of a proliferative marginal zone of retinal progenitors in postnatal chickens. Dev Biol 2000;220(2):197-210.

37. Tsonis PA, Del Rio-Tsonis K. Lens and retina regeneration: transdifferentiation, stem cells and clinical applications. Exp Eye Res. 2004;78(2):161-72.

38. Mitashov VI. Mechanisms of retina regeneration in urodeles. Int J Dev Biol 1996;40(4):833-44.

39. Tsonis PA. Regenerative biology: the emerging field of tissue repair and restoration. Differentiation. 2002;70(8):397-409.

40. Moshiri A, Close J, Reh TA. Retinal stem cells and regeneration. Int J Dev Biol. 2004;48(8-9):1003-14.

41. Mayer EJ, Hughes EH, Carter DA, Dick AD. Nestin positive cells in adult human retina and in epiretinal membranes. Br J Ophthalmol. 2003;87(9): 1154-8.

42. Tropepe V, Coles BL, Chiasson BJ, Horsford DJ, Elia AJ, McInnes RR, et al. Retinal stem cells in the adult mammalian eye. Science. 2000;287(5460): 2032-6.

43. Kicic A, Shen WY, Wilson AS, Constable IJ, Robertson T, Rakoczy PE. Differentiation of marrow stromal cells into photoreceptors in the rat eye. J Neurosci. 2003;23(21):7742-9.

44. Haruta M, Kosaka M, Kanegae Y, Saito I, Inoue T, Kageyama R, et al. Induction of photoreceptor-specific phenotypes in adult mammalian iris tissue. Nat Neurosci. 2001;4(12):1163-4.

45. Zhao X, Das AV, Thoreson WB, James J, Wattnem TE, Rodriguez-Sierra J, et al. Adult corneal limbal epithelium: a model for studying neural potential of non-neural stem cells/progenitors. Dev Biol. 2002;250(2):317-31.

46. Arsenijevic Y, Taverney N, Kostic C, Tekaya M, Riva F, Zografos L, et al. Non-neural regions of the adult human eye: a potential source of neurons? Invest Ophthalmol Vis Sci. 2003;44(2):799-807.

47. Mezey E, Chandross KJ, Harta G, Maki RA, McKercher SR. Turning blood into brain: cells bearing neuronal antigens generated in vivo from bone marrow. Science. 2000;290(5497):1779-82. Comment in: Science. 2000;290 (5497):1672-4.

48. Woodbury D, Schwarz EJ, Prockop DJ, Black IB. Adult rat and human bone marrow stromal cells differentiate into neurons. J Neurosci Res. 2000; 61(4):364-70.

49. Tomita M, Adachi Y, Yamada H, Takahashi K, Kiuchi K, Oyaizu H, et al. Bone marrow-derived stem cells can differentiate into retinal cells in injured rat retina. Stem Cells. 2002;20(4):279-83.
50. Klassen H, Sakaguchi DS, Young MJ. Stem cells and retinal repair. Prog Retin Eye Res. 2004;23(2):149-81.

51. Takahashi M, Palmer TD, Takahashi J, Gage FH. Widespread integration and survival of adult-derived neural progenitor cells in the developing optic retina. Mol Cell Neurosci. 1998;12(6):340-8.

52. Young MJ, Ray J, Whiteley SJ, Klassen H, Gage FH. Neuronal differentiation and morphological integration of hippocampal progenitor cells transplanted to the retina of immature and mature dystrophic rats. Mol Cell Neurosci. 2000;16(3):197-205.

53. Väänänen K. Mechanism of osteoclast mediated bone resorption-rationale for the design of new therapeutics. Adv Drug Deliv Rev. 2005;57(7):959-71

54. Chacko DM, Rogers JA, Turner JE, Ahmad I. Survival and differentiation of cultured retinal progenitors transplanted in the subretinal space of the rat. Biochem Biophys Res Commun. 2000;268(3):842-6.

55. Nishida A, Takahashi M, Tanihara H, Nakano I, Takahashi JB, Mizoguchi A, et al. Incorporation and differentiation of hippocampus-derived neural stem cells transplanted in injured adult rat retina. Invest Ophthalmol Vis Sci. 2000;41(13):4268-74.

56. Otani A, Dorrell MI, Kinder K, Moreno SK, Nusinowitz S, Banin E, et al. Rescue of retinal degeneration by intravitreally injected adult bone marrowderived lineage-negative hematopoietic stem cells. J Clin Invest. 2004; 114(6):765-74. Comment in: J Clin Invest. 2004;114(6):755-7.

57. Kociok N. Can the injection of the patient's own bone marrow-derived stem cells preserve cone vision in retinitis pigmentosa and other diseases of the eye? Graefes Arch Clin Exp Ophthalmol. 2005;243(3):187-8.

58. Streilein JW, Ma N, Wenkel H, Ng TF, Zamiri P. Immunobiology and privilege of neuronal retina and pigment epithelium transplants. Vision Res. 2002;42 (4):487-95

59. Sheedlo HJ, Gaur V, Li LX, Seaton AD, Turner JE. Transplantation to the diseased and damaged retina. Trends Neurosci. 1991;14(8):347-50.

60. Jiang LQ, Jorquera M, Streilein JW. Subretinal space and vitreous cavity as immunologically privileged sites for retinal allografts. Invest Ophthalmol Vis Sci. 1993;34(12):3347-54.

61. Williamson TH, O'Donnell A. Intravitreal triamcinolone acetonide for cystoid macular edema in nonischemic central retinal vein occlusion. Am J Ophthalmol. 2005;139(5):860-6.

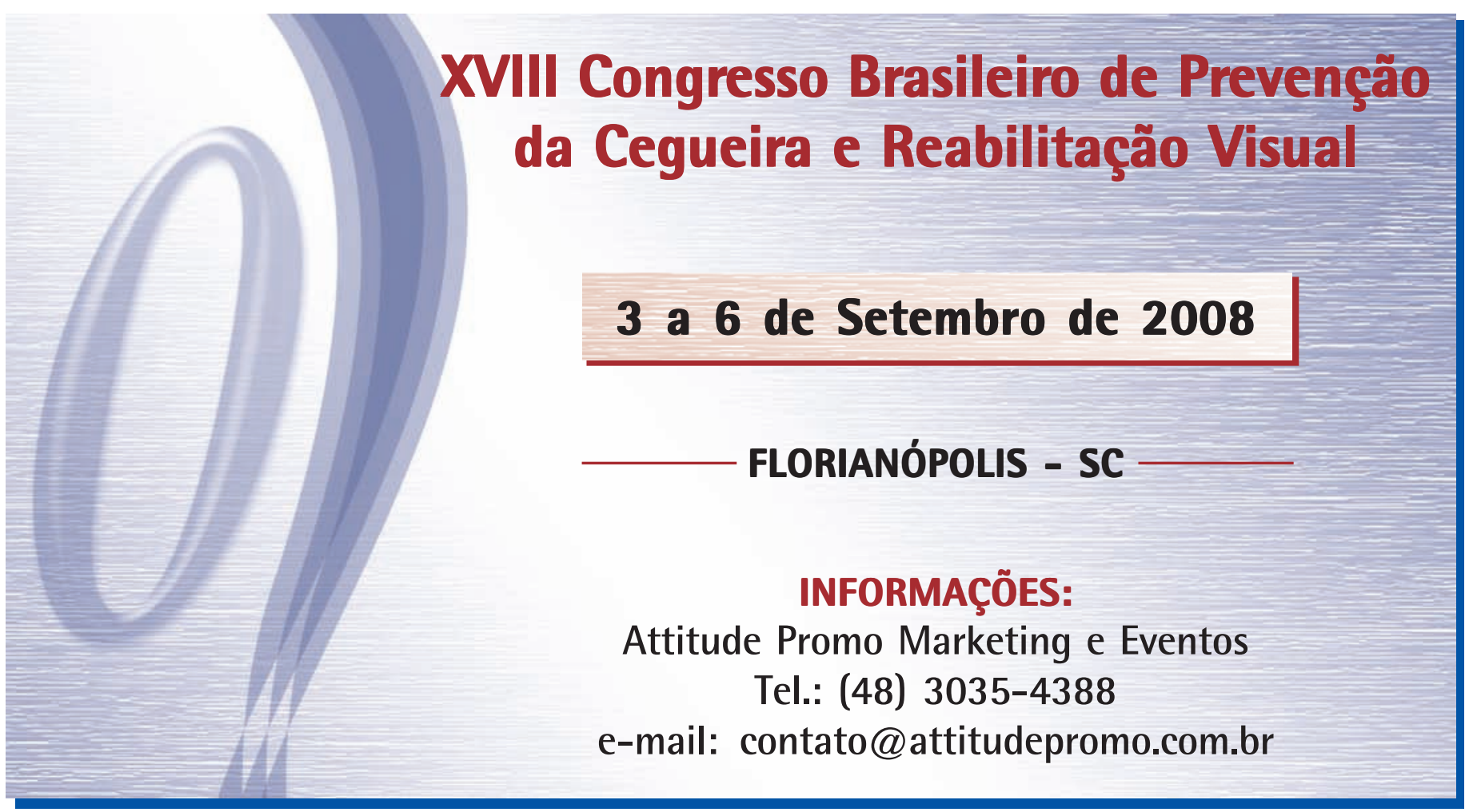

